Neurosurg Focus 23 (3):E13, 2007

\title{
Nelson syndrome: comprehensive review of pathophysiology, diagnosis, and management
}

\author{
Magdalena J. Banasiak, M.D., and Ali R. Malek, M.D. \\ Department of Neurosurgery, University of South Florida, Tampa, Florida
}

\begin{abstract}
$\checkmark$ Nelson syndrome (NS) is a rare clinical manifestation of an enlarging pituitary adenoma that can occur following bilateral adrenal gland removal performed for the treatment of Cushing disease. It is characterized by excess adrenocorticotropin secretion and hyperpigmentation of the skin and mucus membranes. The authors present a comprehensive review of the pathophysiology, diagnosis, and management of NS. Corticotroph adenomas in NS remain challenging tumors that can lead to significant rates of morbidity and mortality. A better understanding of the natural history of NS, advances in neurophysiology and neuroimaging, and growing experience with surgical intervention and radiation have expanded the repertoire of treatments. Currently available treatments include surgical, radiation, and medical therapy. Although the primary treatment for each tumor type may vary, it is important to consider all of the available options and select the one that is most appropriate for the individual case, particularly in cases of lesions resistant to intervention. (DOI: 10.3171/FOC-07/09/E13)
\end{abstract}

\section{KEY WORDS • adrenalectomy • adrenocorticotropic hormone • hyperpigmentation • Nelson syndrome $\bullet$ pituitary adenoma}

$\mathrm{N}$ ELSON syndrome is a rare clinical manifestation of an enlarging pituitary adenoma that can occur following bilateral adrenalectomy performed in the treatment of $\mathrm{CD}$. It is characterized by skin and mucus membrane hyperpigmentation and excess ACTH secretion.

Diagnostic criteria for NS have been quite variable. Some authors ${ }^{77}$ have defined NS as high levels of ACTH associated with skin hyperpigmentation after bilateral adrenalectomy regardless of pituitary enlargement, ${ }^{80}$ whereas others consider the presence of an expanding pituitary adenoma causing visual field disturbance as a requirement for diagnosis. ${ }^{114}$ With modern day imaging, and for the purposes of this review, corticotroph tumor progression and high $\mathrm{ACTH}$ have been proposed as a basis for the diagnosis of NS. ${ }^{4}$

Abbreviations used in this paper: $\mathrm{ACTH}=$ adrenocorticotropic hormone; $\mathrm{CD}=$ Cushing disease CRH = corticotropin-releasing hormone; $\mathrm{CT}=$ computed tomography; $\mathrm{GH}=$ growth hormone; $\mathrm{MR}=$ magnetic resonance; $\mathrm{MSH}=$ melanocyte-stimulating hormone; $\mathrm{NS}=$ Nelson syndrome; TBA = total bilateral adrenalectomy; $\mathrm{TSH}=$ thyroid-stimulating hormone.

\section{Historical Perspective}

The first suggestion that the adrenal gland was essential for life came from Brown-Séquard, who showed in the 1850s that bilateral adrenalectomy in animals caused death within a few days. ${ }^{66}$ Harvey Cushing ${ }^{13}$ was the first to link adrenal hypersecretion of cortisol to the presence of a pituitary tumor. The concept of the hypothalamic-pituitary-adrenal axis evolved further with the demonstration of the existence of ACTH-releasing factor in 1955 by Saffran and Schally. ${ }^{98}$ The first case report of the characteristic triad of NS was published by Don Nelson in $1958 .{ }^{78} \mathrm{He}$ described a 33-year-old woman who developed marked skin hyperpigmentation, high plasma ACTH levels, and imaging evidence of a pituitary tumor (enlarged sella on skull radiographs) 3 years after bilateral adrenalectomy for CD. In 1960, Nelson and colleagues ${ }^{79}$ formally described the syndrome of pituitary hypersecretion of ACTH and pituitary tumor enlargement, which has since become the eponymous syndrome. Corticotropin-releasing hormone was finally isolated and sequenced by Vale and coworkers in $1981,{ }^{113}$ and with the availability of radioimmunoassay, the elevation of plasma ACTH levels after bilateral adrenalectomy became diagnostic for NS.

Historically, patients with $\mathrm{CD}$ were treated with bilateral 
adrenalectomy. ${ }^{77,84}$ Transsphenoidal pituitary surgery has radically modified the management of pituitary-dependent hypercortisolism. It is currently the treatment of choice and has been reported to result in initial remission rates of 70 to $90 \%{ }^{28,61,92,93,96,108}$ The outcomes however, vary depending on tumor size and presence or absence extrasellar invasion. Relapse rates of up to $20 \%$ have been reported, and longterm remission is achieved in only approximately 60 to $70 \%$ of patients with CD. ${ }^{15,81}$ For patients in whom transsphenoidal surgery is unsuccessful, four other treatment options exist: repeated transsphenoidal resection, radiation therapy, medical therapy, and bilateral adrenalectomy. Total bilateral adrenalectomy represents the ultimate treatment in severe cases of persistent hypercortisolism. ${ }^{12}$ Adrenalectomy, performed nowadays with low rates of morbidity and mortality, is the only treatment option that offers immediate control of hypercortisolism with 96 to $100 \%$ certainty. ${ }^{24,116}$ Today TBA is typically performed in patients with nonresectable pituitary adenomas, pituitary tumors in which resection has failed to control symptoms and anticortisolic medications are either ineffective or not indicated (as in pregnancy), no evidence of a pituitary neoplasm despite strong biochemical evidence of CD (results of a high-dose dexamethasone suppression test, inferior petrous sinus sampling, or both), or life-threatening symptomatic CD.

Since Nelson's original description, reports of over 50 series of NS cases have been published. These studies have had several limitations in that most included a small number of patients and the data in all were retrospective. Also, the definitions and diagnostic criteria have changed over time as the fields of neuroimaging and biochemistry have evolved. Prior to CT and MR imaging, pituitary microadenomas could not be visualized, and macroadenomas were identified by sellar x-ray tomography. Diagnosis initially relied on the physical examination and plasma ACTH measurements. High levels of ACTH secretion were defined based on qualitative assessment of associated cutaneous hyperpigmentation or on various arbitrary cut-off points for plasma ACTH concentration. Selective irradiation of pituitary adenomas only became feasible in the 1990s, after high-resolution CT and MR imaging became available for use in dose planning. Groups of patients received different treatments, some of which (for example, pituitary radiotherapy) may have directly impacted pituitary tumor growth. Finally, major technological and medical advances, such as pituitary MR imaging and the development of transsphenoidal surgical techniques, altered the diagnostic criteria and outcomes during the period of data acquisition. Consequently, data from these series can be difficult to compare, interpret, and apply to modern clinical practice.

\section{Characteristics of Nelson Syndrome}

\section{Demographic Features}

The ACTH-secreting adenomas represent approximately 10 to $12 \%$ of all pituitary adenomas and are seen predominantly in women (female/male ratio 8:1); the peak incidence is in the third to fourth decades of life. ${ }^{71,111}$ Middleaged women, therefore, constitute the largest group at risk for NS. Although generally benign, ACTH-producing tumors are more invasive than most other pituitary adeno- mas. The rates of NS in patients who had undergone adrenalectomy ranged from 8 to $42 \%$ in the largest series, ${ }^{12,46}$, $48,72,106$ and higher rates (up to $47 \%$ ) have been reported in studies in which MR imaging and modified diagnostic criteria were used. ${ }^{4,85}$ In the largest pediatric case series NS was reported in 25 to $66 \%$ of children who had undergone adrenalectomy. ${ }^{33,109}$ The incidence of NS increased with prolonged follow-up, possibly indicating that there is a spectrum of disease ranging from small and slowly growing tumors to those that are more aggressive and produce symptoms earlier. A molecular mechanism for this variability has yet to be identified.

\section{Pathophysiology of the Disease}

Nelson syndrome usually occurs 1 to 4 years after TBA (range 2 months-24 years) ${ }^{24,77}$ and can be regarded an iatrogenic disease. The classical thinking was that NS results from the loss of feedback control of serum cortisol on the hypothalamus and pituitary gland. Following TBA, cortisol levels that had previously suppressed hypothalamic CRH production normalize, resulting in an increase in CRH production. Adrenalectomy in rats increases hypothalamic $\mathrm{CRH}$ transcription, and is followed by a moderate increase in corticotroph cell numbers. ${ }^{68}$ Because most adenomatous corticotrophs still retain their responsiveness to $\mathrm{CRH}$, elevation of the CRH level exerts a trophic effect on the residual tumor cells, stimulating their growth and increasing propiomelanocortin production. Evaluating postadrenalectomy CRH production in humans has been more challenging; thus the role of $\mathrm{CRH}$ in stimulating the proliferation of corticotroph adenoma after adrenalectomy remains, to some extent, speculative. ${ }^{4}$

The corticotroph adenoma cells that are responsible for the $\mathrm{CD}$ in the first place are believed to be the source of the tumor that eventually grows and leads to NS development. ${ }^{3}$ In most corticotroph adenomas in patients with NS, the products of propiomelanocortin transcription and processing are similar to those in normal anterior pituitary corticotrophs, except that in NS, these products are produced in greater amounts. ${ }^{7}$ The ACTH response to $\mathrm{CRH}$ in these patients also differs from the response in those who have adenomas of CD in two ways: the magnitude is greater, and the response is prolonged. These differences may be explained by the greater size of the tumor and the reduced glucocorticoid feedback in patients who have undergone adrenalectomies and have NS. ${ }^{83}$ Cleavage of excessively produced propiomelanocortin to ACTH and MSH is critical in NS; MSH is responsible for the increased pigmentation seen in these patients. In NS, plasma ACTH levels remain elevated in a stable fashion and demonstrate less diurnal fluctuation, indicating a process to some degree independent of phasically released $\mathrm{CRH}^{40,42,101,122}$ Basal ACTH secretion was increased sixfold and pulsatile secretion was increased ninefold in patients with NS compared with patients with CD. ${ }^{113}$

All patients who undergo TBA are treated with physiological steroid replacement, typically an equivalent of 30 $\mathrm{mg}$ of hydrocortisone per day. Some authors have speculated that differences in the maintenance dose and frequency of glucocorticoid administration after bilateral adrenalectomy might account in part for the variable prevalence of NS after adrenalectomy for CD. ${ }^{41,77,85,90}$ When the inhibitory 
Pathophysiology, diagnosis, and management of Nelson syndrome

influence of steroids is insufficient for longer periods, as in cases in which replacement of glucocorticoid hormones has not been adequate, pituitary ACTH-producing cells can be stimulated excessively, which in turn can lead to adenomatous transformation of these cells, resulting in NS. ${ }^{77,111,114}$

What remains intriguing in the pathophysiology of NS is the lack of responsiveness of adenocorticotroph cells to steroid hormone replacement therapy. Partial resistance to glucocorticoids in a monoclonal pituitary adenoma has been found in corticotroph adenomas. ${ }^{7}$ The NS adenomas, like the corticotroph adenomas in general, show a defective response or a partial resistance to glucocorticoid hormones. This has been demonstrated by the results of in-vivo studies showing that ACTH plasma levels are not normally suppressed by glucocorticoid hormone administration in patients with NS. ${ }^{120}$ Regulatory gene mutations and mutations in the glucocorticoid receptor may also be important in determining the behavior of the tumor leading to local resistance to negative glucocorticoid feedback. It has been suggested that a somatic glucocorticoid receptor defect might play a pathophysiological role in the tumorigenesis of the corticotropinoma bearing this mutation. ${ }^{39}$

Controversy remains as to whether the pituitary ACTH adenoma tumor progression in NS is a result of the lack of cortisol feedback after adrenalectomy or reflects corticotroph tumors that were programmed to behave in an aggressive manner. ${ }^{24}$ The search for the possible molecular mechanisms responsible for the pathogenesis of corticotroph adenomas has been recently reviewed. ${ }^{14}$ A number of possible mechanisms have been investigated, including oncogenes, tumor suppressor genes, growth factors, transcription factors, various signaling pathways, cell-cycle associated genes, and angiogenic factors. Unfortunately, no definitive information is yet available on the molecular pathogenesis of corticotroph adenomas. The pathophysiology of accelerated tumor growth remains poorly understood, ${ }^{3}$ and it is still unclear whether adrenalectomy accelerates corticotroph tumor growth. ${ }^{69}$ Somatic modification may play an important role in the pathogenesis of corticotroph adenomas, allowing monoclonal expansion of a genetically aberrant cell. ${ }^{23}$

\section{Histopathological Findings}

Although pituitary tissue obtained in patients with NS has been found to show molecular features essentially identical to those observed in $\mathrm{CD},{ }^{8} \mathrm{NS}$-associated adenomas are often larger, more invasive, and more aggressive than those causing CD. ${ }^{77}$ These tumors are of monoclonal origin ${ }^{32}$ and are basophilic as well as periodic acid-Schiff-positive. Immunostaining also demonstrates the presence of ACTH, $\mathrm{MSH}$, and related peptides in the cytoplasm of these tumors. The few ultrastructural features different from those of adenomas in CD are inconspicuous or absent Type 1 filaments and a lack of Crooke hyaline changes (present only with excess cortisol). None of the pathological features of the tumors have thus far correlated with prediction of corticotroph tumor progression. ${ }^{4}$

The tumors of NS may have cytological features that include increased cellular proliferation, with mitoses and cellular and nuclear pleomorphism. At the molecular level, this aggressive behavior may reflect the development of genetic mutations in oncogenes and genes regulating pitu- itary growth and differentiation, although this has not been elucidated. Molecular studies on p53 expression have found nuclear and/or cytoplasmic accumulation of p53 in $50 \%$ of noninvasive and $69 \%$ of invasive ACTH-secreting tumors. Nuclear accumulation of p53 protein is associated with a significantly lower apoptotic index indicating a failure of p53 protein to exert its apoptotic action in at least a subset of this tumor type..$^{11,52}$ Other authors have not been able to reproduce these results, ${ }^{39}$ and the implications of this molecular expression remain to be determined.

Machado et al. ${ }^{59}$ studied DNA flow cytometry of pituitary adenomas in NS and CD and found the highest proliferation rates in NS tumors. Histological invasiveness was directly associated with increased proliferation rates. These authors proposed that DNA flow cytometry could be used to identify those patients with pituitary tumors with a higher invasive potential and risk of NS.

\section{Patient Identification and Treatment}

\section{Diagnosis}

The presentation of patients with NS is variable and the criteria used in the diagnosis of the syndrome have evolved over time. Historically, tumor enlargement was diagnosed by radiographic evidence of sellar enlargement, and increased ACTH production was often inferred from diffuse hyperpigmentation. Today, with modern neuroimaging techniques and the wide availability of immunoassays, the clinical diagnosis of NS is easier. The majority of authors refer to a triad of a plasma ACTH level above $200 \mathrm{ng} / \mathrm{L}$ (normal levels are below $54 \mathrm{ng} / \mathrm{L}$ ), imaging (MR imaging, unless contraindicated) evidence of pituitary mass enlargement, and hyperpigmentation. Hyperpigmentation, which occurs later in the disease process, is present in only $42 \%$ of cases in modern series, ${ }^{46}$ probably reflecting the fact that NS is now generally diagnosed at an earlier stage. The mere presence of a pituitary adenoma postoperatively, even with mild elevations of plasma ACTH levels, is not always followed by the disastrously progressive problems that some patients experience. Therefore, evidence of tumor progression is a necessary requirement for the diagnosis of NS. ${ }^{85}$

Signs and Symptoms. Complications related to NS are essentially due to tumor growth. The spectrum of clinical features observed relates to the local effects of the tumor on surrounding structures and the secondary loss of pituitary hormones. Compression by the tumor can inhibit the release of any of the anterior pituitary hormones and may also occasionally lead to diabetes insipidus. ${ }^{94}$ A large tumor can cause visual deficits through compression of the optic pathways; such visual deficits have been reported in 10 to $57 \%$ of cases. ${ }^{26,37,43,48,62,65,77,109,121}$ The high rates of visual deficits seem to be in accordance with the lesion's welldocumented aggressive behavior. ${ }^{77,96}$ If a tumor invades the cavernous sinus it can cause diplopia and cranial nerve lesions by involving the oculomotor, trochlear, abducent and V1 and V2 branches of the trigeminal nerve. ${ }^{65}$ Tumor necrosis with sudden intracranial hypertension has also been described. ${ }^{18,41}$ Features of raised intracranial pressure can occur late and are uncommon as they require a tumor large enough to obstruct the flow of cerebrospinal fluid. Headaches can occur and are probably the result of stretch- 
ing of the diaphragma sellae. Malignant conversion to pituitary carcinoma with distant metastases, while rare, has also been described. .3, $55,58,72,86,121$ Brain invasion is associated with aggressive adenomas that have been resistant to prior interventions. ${ }^{46}$

Hyperpigmentation of the skin is usually obvious and is not limited to sun-exposed areas. The degree of pigmentation varies depending upon ethnicity as well as levels of MSH. Patients with hyperpigmention usually present with a linea nigra and pigmentation of the extensor surfaces, scars, gingivae, and areolae.

Paratesticular and paraovarian tumors producing cortisol or androgens in an ACTH-dependent manner have been described. ${ }^{5,82,107}$ During embryogenesis, adrenal cortical cells may migrate along the line of gonadal descent or become sequestered in the hilum of the testes, giving rise to adrenal rest tissue. In NS, this adrenal rest tissue may become stimulated. When in the testes, it can result in painful testicular enlargement and oligospermia. Rarely, the adrenal rest tissue can produce sufficient cortisol to normalize levels or even cause recurrence of CD. ${ }^{38,82,100}$

Predictive Risk Factors. Much effort has been directed towards the identification of predictive factors for the development of NS. The ability to forecast which patients are at risk would facilitate earlier detection and treatment of a smaller tumor burden with a lower morbidity rate. Also, other treatment options could be weighed against adrenalectomy in higher risk patients.

The presence of high basal plasma ACTH levels after adrenalectomy is the best validated risk factor., $4,2,24,37,41$, 48,73,77,85 No unique threshold value has been defined. Assie et al. ${ }^{4}$ found levels above $100 \mathrm{ng} / \mathrm{L}$ in the year following adrenalectomy to be predictive of NS. Young age at the time of adrenalectomy, with a corresponding higher incidence of NS in children, has been reported, 33,36,49,109 but this is not universally accepted. ${ }^{4} \mathrm{~A}$ shorter duration of $\mathrm{CD}^{4,48}$ and the presence of a pituitary tumor prior to adrenalectomy have also been identified as predictive in several series. ${ }^{4,29,37,85,105}$ High urinary cortisol excretion before adrenalectomy was seen in some studies ${ }^{77,105}$ but not all. . $^{6,48,85}$ Likewise, residual cortisol secretion was found predictive in some ${ }^{62,85}$ but not all reports. ${ }^{4}$ The results of a few recent retrospective studies ${ }^{41,77,90}$ have suggested that an insufficient dose of glucocorticoid substitution treatment after adrenalectomy may be linked to the development of NS. This hypothesis, however, is not supported by the results of a number of earlier studies. ${ }^{6,43,48}$ The presence of mitoses or a high percentage of Ki 67-immunopositive nuclei in the adenoma has also been identified as a potential predictor of corticotroph tumor progression ( $\mathrm{Ki} 67 \geq 3 \%),{ }^{4,74}$ but this finding remains controversial. ${ }^{4}$

A negative predictor for the development of NS has been the use of prophylactic radiotherapy after adrenalectomy, ${ }^{24,37,46,77}$ although neither the predictive value nor the clinical significance of the association is universally accepted. ${ }^{62,64,72,85,105}$

Some factors that have never been demonstrated to have predictive value for development of NS include gender ${ }^{49,72}$, ${ }_{77,105}$ and plasma ACTH concentration prior to adrenalectomy. ${ }^{6,36,49,105}$

Laboratory Studies. The only laboratory investigation required for the diagnosis of NS is a plasma ACTH level.
Normal values are below $54 \mathrm{ng} / \mathrm{L}$ and levels above 200 $\mathrm{ng} / \mathrm{L}$ have been generally considered diagnostic for NS. 37,50 (Authors of several studies used pmol/L units; $1 \mathrm{ng} / \mathrm{L}$ is equivalent to $0.225 \mathrm{pmol} / \mathrm{L}$.) The plasma ACTH levels in $\mathrm{CD}$ are normal or only slightly elevated, whereas in NS they are markedly elevated, usually in the range of thousands of $n g / L$. Pereira et al. ${ }^{85}$ found that levels of 154 $\mathrm{pmol} / \mathrm{L}$ or greater were only present in patients with NS. Other derivatives of the precursor peptide, propiomelanocortin, are also elevated, although their measurement is not required for diagnosis. Patients with NS will also often have an exaggerated ACTH response to CRH. Although blood levels of ACTH are generally markedly elevated in patients with NS, hypercortisolemia is absent.

Other laboratory investigations that should be considered as part of the evaluation of a patient with possible NS include a general pituitary panel to evaluate preexisting and/or identify new pituitary dysfunction as well as to address the adequacy of hormone replacement therapy. These studies may include (as clinically indicated) evaluation of blood levels of free thyroxine (T4) and TSH, prolactin, GH, insulin-like growth factor-1, gonadotropinreleasing hormone, luteinizing hormone, follicle stimulating hormone, and testosterone, and urine osmolality or specific gravity.

Imaging Studies. There are no specific imaging studies for the diagnosis of NS. Magnetic resonance imaging provides the best means of visualizing the sellar region and can be considered a reliable guide for surgeons before and during the operation.

The diagnosis of NS requires demonstration of corticotroph tumor progression. Because the majority of patients have previously undergone at least one transsphenoidal procedure, comparison with postoperative images is of major importance. This comparison is particularly critical in the presence of residual tumor after incomplete resection of a pituitary adenoma.

The progression of a corticotroph tumor is best identified with MR imaging. Magnetic resonance imaging techniques that facilitate detection of ACTH-secreting adenomas responsible for CD and NS include high-resolution (3-mm cuts) coronal T1- and T2-weighted sequences, dynamic MR imaging, and post-gadolinium administration delayed images with gadolinium dose adjustment for each sequence. Protocols such as this can routinely demonstrate pituitary adenomas smaller than $3 \mathrm{~mm}$ in diameter.,10 Smaller ACTH-secreting pituitary adenomas may evade detection with MR imaging.

Ectopic corticotroph adenomas are extremely rare, and ectopic pituitary adenomas causing symptoms of NS are even rarer. ${ }^{19,89}$ These tumors frequently extend beyond the boundaries of the sella turcica. Infiltration of the cavernous sinus, sphenoid sinus, or clivus, compression of the optic chiasm, and encasement of the internal carotid artery can all be present. Over $90 \%$ of macroadenomas lead to enlargement of the osseous pituitary fossa. Intratumoral hemorrhage may also be seen. Microadenomas are best seen on coronal images and usually appear hypo- or isointense relative to normal pituitary tissue on unenhanced T1weighted images. After the administration of a contrast agent, the microadenoma usually remains hypointense due to the earlier and more intense enhancement of normal pitu- 
Pathophysiology, diagnosis, and management of Nelson syndrome

itary tissue. Indirect imaging features of microadenomas may be a one-sided elevation of the diaphragm or prolapse of the pituitary fossa. In dynamic sequences after rapid injection of contrast medium, a diminished and delayed enhancement of the adenoma may be seen. Some microadenomas demonstrate an early arterial enhancement, occurring simultaneously with enhancement of the posterior lobe, but compared with normal pituitary tissue most microadenomas display slightly lower signal intensity. ${ }^{97}$ For those patients in whom MR imaging is contraindicated, thin-cut CT with coronal and sagittal reconstructions and intravenous administration of a contrast agent can be used instead.

A baseline MR imaging study is recommended 3 months after surgery, as maximal extension of the pituitary mass does not return to normal immediately postoperatively (even with total tumor removal). This interval allows postoperative changes to resolve while still not risking significant growth from any residual tumor. Contrast-enhanced images obtained immediately (on the first postoperative day) following resection may also be reliable for visualization of residual tumor, with fat-suppressed sequences enabling discrimination between a fat pad and enhancing adenoma. ${ }^{97}$

Ophthalmological Testing. All patients who have large masses in the region of the pituitary or the optic nerves should be referred for formal visual field assessment by an ophthalmologist. Children do not always report visual symptoms and therefore benefit from periodic ophthalmological evaluations.

\section{Treatment Options}

Today, with greater awareness of NS and with the availability of modern neuroimging and immunoassays, tumor progression can be detected much earlier and thus at a smaller lesion size. Surgery remains the primary mode of therapy. Radiotherapeutic protocols offer additional options for treatment. ${ }^{60}$ Although not widely accepted, some pharmacotherapeutic measures can also be offered to patients with resistant lesions. If untreated, NS adenomas often become markedly aggressive and may cause death in some patients, usually through brain invasion.

Surgery. Still the best hope for cure in cases of NS, surgery is the treatment of choice for large tumors that produce acute compression of the optic apparatus and other vital structures..$^{27,41,46,123}$ The goal of surgery is to remove all macroscopic tumor tissue without compromising vital structures. The choice of transsphenoidal or cranial approach depends on the degree of extrasellar extension, which is demonstrated in $33 \%$ of cases at the time of NS diagnosis. ${ }^{15}$ As in other pituitary adenomas, surgical treatment of NS tumors is more effective when the tumors are relatively small, and when surgery is performed before extrasellar expansion of the tumor occurs, it may result in long-lasting remissions. ${ }^{50}$ Other determinants of surgical success include the degree of tumor invasion of brain parenchyma, optic apparatus, cavernous sinuses, dura mater, and bone, as well as the experience of the surgeon.

In a recent study involving long-term follow-up of 56 patients with NS, 13 patients required surgical intervention because of an expanding pituitary mass (nine transsphenoidal hypophysectomies and four craniotomies). Control of the neoplasm was achieved in $70 \%$ and the disease remained stable in $15 \%$. No visible tumor was found in $85 \%$ on postoperative MR images. In $15 \%$ of the patients, the disease persisted and lead to tumor progression and death. Also, $85 \%$ of patients recovered normal pigmentation, and all experienced at least partial improvement. The plasma ACTH levels decreased in all patients (median decrease $84 \%$, range 56-99\%). ${ }^{46}$ Xing et al. surgically treated 23 patients with NS (performing 21 transsphenoidal procedures and two craniotomies) and reported curative and remission rates of 57 and $26 \%$, respectively. ${ }^{121}$ De Tommasi et al. ${ }^{15}$ reported that among six patients with NS treated with surgery alone or surgery and radiation, only one $(16.6 \%)$ experienced remission. General efficacy rates of neurosurgery for NS have been reported at between 10 and 70\%. ${ }^{15,21,46,50,120}$ In cases of incomplete removal or where invasion is present, adjunctive irradiation reduces the rate of recurrence and improves the prognosis.

Surgical complications are similar to those for initial or repeated transsphenoidal pituitary resection or craniotomy. Reported rates of perioperative complications remain relatively low, with a documented mortality rate of 5\% (a single patient in one study), visual loss $0 \%$, cranial nerve deficits $5 \%$, cerebrospinal fluid leak $15 \%$, and meningitis $8 \% .{ }^{46,63,121}$ Occurrence of treatment-associated hypopituitarism can be as high as $69 \%$, particularly with large tumors. Permanent diabetes insipidus was reported in $38 \%$ of patients. Frequently, the aggressive and locally invasive nature of tumors in NS necessitates radical hypophysectomy. Not surprisingly, an increased prevalence of panhypopituitarism and diabetes insipidus results. Nevertheless, the procedure is relatively safe and well tolerated and offers rapid and long-lasting resolution of the mass effect. ${ }^{46}$

Radiation Therapy. Radiation is another alternative treatment for patients in whom surgery has been unsuccessful or is not an option. ${ }^{110}$ Radiotherapy administered to the pituitary at the time of adrenalectomy has been correlated with a lower risk for NS in some series. ${ }^{24,37,46,77}$ Once NS occurs, prophylactic pituitary irradiation cannot prevent the disease from progressing, especially in patients with adenomas that secrete large amounts of ACTH. ${ }^{121}$ While the use of prophylactic radiotherapy at the time of adrenalectomy has been proposed, the suggestion has not been translated into common practice. Given the risks of sellar radiation, the inconsistent protective relationship, and the relatively low rates of NS in patients who have undergone adrenalectomy, routine prophylactic irradiation is not justified based on currently available data. Thus far there has been no agreement on the optimal time of intervention in patients with NS. Some advocate early treatment, ${ }^{37,50}$ whereas others are proponents of close follow-up and intervention only with evidence of disease progression. ${ }^{3}$

Fractionated radiation therapy has been used to control ACTH secretion and tumor growth in patients in whom surgical intervention for CD and NS has failed and in those with recurrent tumors. ${ }^{20,34,60}$ The typical total dose of 45 to 54 Gy is delivered in 1.8- to 2-Gy daily fractions. ${ }^{20}$ After fractionated radiation therapy, a decrease in circulating ACTH levels and improved hyperpigmentation was observed in $14(93 \%)$ of 15 patients with NS.34

Stereotactic radiosurgery has been frequently used to cure or control pituitary adenomas during the past 2 
decades. The differences in the imaging used for locating the target, the radiation source, dosimetry, length of followup, and the method of defining tumor remission make comparison of the data across studies difficult. ${ }^{67}$ Other shortcomings of the data are the lack of prospective randomization and the short follow-up periods in the studies. Nevertheless, stereotactic radiosurgery has been shown to be an effective tool in controlling tumor growth in the majority of patients who have residual tumor after transsphenoidal surgery for CD. . $^{16,20,22,35,51,63,90,99}$

Gamma Knife surgery has also been successfully used in NS. ${ }^{22,51,63,90,119}$ Initial results reported by Pollock et al. ${ }^{90}$ seemed very promising, with rates of tumor control reported at $82 \%$ in 11 patients treated, at a median of 37 months' follow-up. The median plasma ACTH level decreased $66 \%$, and approximately one half of the patients with hyperpigmentation had improvement in their skin coloration. Complications in this series occurred exclusively in patients who had undergone prior fractionated radiation therapy (diplopia in two patients and ipsilateral blindness, hormone deficiency, and temporal lobe radiation necrosis in one each). Of six patients treated with Gamma Knife surgery by Kobayashi et al., ${ }^{51}$ a partial response in tumor size was achieved in two (33\%), a minor response was achieved in two (33\%), and no change occurred in two (33\%). A decrease in hormone levels occurred in two cases, and hormone levels remained unchanged in two cases. The rates of response in patients with NS were noted to be lower than in those with CD. Mauermann et al. ${ }^{63}$ treated 20 patients with NS by means of Gamma Knife surgery. Of those, 67\% experienced reduction of plasma ACTH levels (mean reduction $75 \%$ ) and $17 \%$ experienced normalization of plasma ACTH levels. Decrease in tumor size was observed in $50 \%$ and stabilization in $40 \%$, for an overall tumor control rate of $90 \%$. Mean imaging follow-up was 20 months (range 0-124 months). Complication-related follow-up was incomplete, but in five of 10 cases in which there was endocrinological follow-up, new hormone deficiencies were observed (including one case of diabetes insipidus). One patient developed a permanent third cranial nerve palsy.

Radiotherapy is associated with serious long-term consequences, including learning and memory difficulties, hypopituitarism, visual damage, and risk of secondary tumors. ${ }^{110}$ Radiation-related complication rates are widely discussed in articles analyzing outcomes of CD treatment. High rates of radiation-induced hypopituitarism in NS - up to $82 \%$ - have been described. ${ }^{35,63,67,110}$ Some abnormalities did not become evident until 10 years after treatment. ${ }^{35} \mathrm{Op}-$ tic neuropathy occurs in fewer than $2 \%$ of patients who have undergone radiosurgery, especially when doses to optic structures are limited to less than $8 \mathrm{~Gy}{ }^{25}$ Higher rates have been described for conventional radiotherapy. Although there is an associated risk of secondary neoplasm, no instances have been reported in the patients who underwent radiosurgery for NS, which is probably related to the limited number of patients studied and relatively short follow-up windows. The treatment-related mortality rate is essentially zero. ${ }^{35}$

Several concerns in planning radiosurgery for NS arise from the propensity of NS adenomas to grow faster and invade more readily than do most $\mathrm{ACTH}$-secreting tumors in $\mathrm{CD}$. Tumor progression can occur before the delayed effect of radiosurgery (mean 1 year) takes place. The minimum effective dose to the tumor margin is the main element determining tumor response. ${ }^{110}$ Proximity to the optic nerves or chiasm may exclude some larger tumors from radiosurgical treatment, unless the nerve is already nonfunctional. Cavernous sinus invasion can be subtle even on MR images, and the borders of an invasive adenoma, particularly the borders of a subtotally resected tumor admixed with postoperative fibrosis, can be difficult to delineate with enough certainty to protect adjacent brain from radiotoxicity. A history of prior irradiation of the sella, commonly encountered in patients with NS, may limit the dose possible in radiosurgery. ${ }^{37}$

Pharmacological Therapy. Much progress has been made in recent years in the pharmacological control of pituitary tumors, with prolactinomas and $\mathrm{GH}$ - and TSH-secreting adenomas being successfully treated with dopaminergic and somatostatinergic drugs. Unfortunately, none of the drugs tested thus far have consistently provided reproducible efficacy in the treatment of NS and no well-established medical therapy for CD or NS currently exists. ${ }^{81,115}$ Nevertheless, the following agents have shown some positive effects and may be useful options when all other treatments fail.

Dopamine Agonists. Bromocriptine, cabergoline, and cyproheptadine have all been studied, but variable results have relegated these agents to be used for adjunctive therapy to lower plasma ACTH levels in select cases. ${ }^{53,70,88,102,103,118}$

Valproic Acid. Sodium valproate may lower, but not normalize, plasma ACTH levels by inhibiting the release of CRH without reducing tumor size, but the results of studies

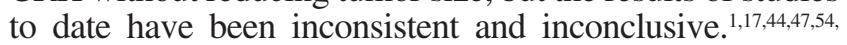
$56,57,70,95$

Somatostatin Analogues. Octreotide and other somatostatin analogues have been shown to reduce plasma ACTH levels in NS but not in patients with untreated pituitarydependent $\mathrm{CD}$, and the results of some studies have even suggested stabilization of tumor growth with some agents. ${ }^{112}$ For now, these agents may provide a useful shortterm measure, to be used as a bridge before other therapies can be implemented. ${ }^{44,45,87,117}$

Rosiglitazone. Peroxisomal proliferator-activated receptors- $\gamma$ are expressed abundantly in ACTH-secreting pituitary tumors..$^{75}$ Data from animal studies has suggested that high-dose peroxisomal proliferator-activated receptors- $\gamma$ agonists, such as rosiglitazone, retarded tumor growth and lowered ACTH and cortisol levels, but only modest reductions in plasma ACTH levels and no tumor regression have thus far been seen in human studies. ${ }^{2,30,31,75,76}$

Serotonin Antagonists. Ketanserin and cyproheptadine have demonstrated transient reductions in plasma ACTH levels and possible reduction in tumor size, ${ }^{91,104}$ but this effect has not been consistently reproduced. ${ }^{50}$

\section{Follow-Up Studies}

There is currently no widely accepted follow-up schedule for patients with NS. Most cases of corticotroph tumor progression can be diagnosed within 3 years of adrenalec- 
tomy, ${ }^{37}$ so patients should be monitored more closely during this initial postoperative period. ${ }^{4}$

Tumor volume can be indirectly monitored with measurements of circulating ACTH levels. ${ }^{50}$ This method offers a simple and rather inexpensive means of screening, which can be used every 3 to 6 months during the first year, every 6 months during the 2nd and 3rd year, and yearly after that. Serial MR imaging is also essential to monitor for any adenoma progression. In the vast majority of patients, yearly MR imaging studies were found to be sufficient to identify disease progression prior to evolution of clinical symptoms related to tumor enlargement. Plasma ACTH values above $100 \mathrm{ng} / \mathrm{L}$ should prompt an MR imaging study of the pituitary to look for tumor progression. ${ }^{4}$ If plasma ACTH levels remain low, the imaging interval can be extended to every other year, after the initial 3 years of annual monitoring.

\section{Conclusions}

Adrenalectomy performed for CD carries significant but not uniform risk for corticotroph tumor progression. Currently, plasma ACTH levels above $200 \mathrm{ng} / \mathrm{L}$ along with MR imaging or CT evidence of tumor growth are sufficient for the diagnosis of NS. Tumors in NS are typically large, invasive pituitary macroadenomas that present a major therapeutic challenge. The only preadrenalectomy predictive factor strongly linked to increased risk for NS development is the presence of a residual corticotroph adenoma following attempted resection. Postadrenalectomy, elevated levels of ACTH during the first year help to identify those at high risk. The most effective and safe treatment option for NS is surgical intervention, which can then be augmented by radiosurgery if complete resection is not possible. So far, the results of pharmacotherapeutic interventions have been disappointing and inconsistent, but pharmacotherapy may provide a last resort option in cases of resistant tumors. Future molecular characterization and a better understanding of the pathophysiology of pituitary corticotroph tumors may lead to the development of tumortargeted therapies.

\section{References}

1. Ambrosi B, Bochicchio D, Riva E, Faglia G: Effects of sodiumvalproate administration on plasma ACTH levels in patients with ACTH hypersecretion. J Endocrinol Invest 6:305-306, 1983

2. Andreassen M, Kristensen L $\varnothing$ : Rosiglitazone for prevention or adjuvant treatment of Nelson's syndrome after bilateral adrenalectomy. Eur J Endocrinol 153:503-505, 2005

3. Assié G, Bahurel H, Bertherat J, Kujas M, Legmann P, Bertagna X: The Nelson's syndrome . . . revisited. Pituitary 7:209-215, 2004

4. Assié G, Bahurel H, Coste J, Silvera S, Kujas M, Dugué MA, et al: Corticotroph tumor progression after adrenalectomy in Cushing's Disease: a reappraisal of Nelson's Syndrome. J Clin Endocrinol Metab 92:172-179, 2007

5. Baranetsky NG, Zipser RD, Goebelsmann U, Kurman RJ, March $\mathrm{CM}$, Morimoto I, et al: Adrenocorticotropin-dependent virilizing paraovarian tumors in Nelson's syndrome. J Clin Endocrinol Metab 49:381-386, 1979

6. Barnett AH, Livesey JH, Friday K, Donald RA, Espiner EA: Comparison of preoperative and postoperative ACTH concentrations after bilateral adrenalectomy in Cushing's disease. Clin Endocrinol (Oxf) 18:301-305, 1983
7. Bertagna X: Unrestrained production of proopiomelanocortin (POMC) and its peptide fragments by pituitary corticotroph adenomas in Cushing's disease. J Steroid Biochem Mol Biol 43: 379-384, 1992

8. Bertagna X, Raux-Demay MC, Guilhaume B, Girard F, Luton JP: Cushing's disease, in Melmed S (ed): The Pituitary, ed 2. Boston: Blackwell Publishing, 2002, pp 496-560

9. Bonneville JF, Cattin F, Bonneville F, Schillo F, Jacquet G: [Pituitary gland imaging in Cushing's disease.] Neurochirurgie 48:173-185, 2002 (Fr)

10. Buchfelder M, Nistor R, Fahlbusch R, Huk WJ: The accuracy of $\mathrm{CT}$ and MR evaluation of the sella turcica for detection of adrenocorticotropic hormone-secreting adenomas in Cushing disease. AJNR Am J Neuroradiol 14:1183-1190, 1993

11. Buckley N, Bates AS, Broome JC, Strange RC, Perrett CW, Burke CW, et al: p53 Protein accumulates in Cushings adenomas and invasive non-functional adenomas. J Clin Endocrinol Metab 79:1513-1516, 1994

12. Chapuis Y, Pitre J, Conti F, Abboud B, Pras-Jude N, Luton JP: Role and operative risk of bilateral adrenalectomy in hypercortisolism. World J Surg 20:775-780, 1996

13. Cushing H: The basophil adenomas of the pituitary body and their clinical manifestations (pituitary basophilism). Bull. John Hopkins Hosp 50:137-195, 1932

14. Dahia PL, Grossman AB: The molecular pathogenesis of corticotroph tumors. Endocr Rev 20:136-155, 1999

15. De Tommasi C, Vance ML, Okonkwo DO, Diallo A, Laws ER Jr: Surgical management of adrenocorticotropic hormone-secreting macroadenomas: outcome and challenges in patients with Cushing's disease or Nelson's syndrome. J Neurosurg 103: 825-830, 2005

16. Degerblad M, Rahn T, Bergstrand G, Thoren M: Long-term results of stereotactic radiosurgery to the pituitary gland in Cushing's disease. Acta Endocrinol (Copenh) 112:310-314, 1986

17. Dornhorst A, Jenkins JS, Lamberts SW, Abraham RR, Wynn V, Beckford U, et al: The evaluation of sodium valproate in the treatment of Nelson's syndrome. J Clin Endocrinol Metab 56: 985-991, 1983

18. Ernest I, Ekman H: Adrenalectomy in Cushing's disease. A longterm follow-up. Acta Endocrinol Suppl (Copenh) 160:3-41, 1972

19. Esteban F, Ruiz-Avila I, Vilchez R, Gamero C, Gomez M, Mochon A: Ectopic pituitary adenoma in the sphenoid causing Nel son's syndrome. J Laryngol Otol 111:565-567, 1997

20. Estrada J, Boronat M, Mielgo M, Magallón R, Millan I, Díez S, et al: The long-term outcome of pituitary irradiation after unsuccessful transsphenoidal surgery in Cushing's disease. N Engl J Med 336:172-177, 1997

21. Fukushima T: Trans-sphenoidal microsurgical treatment of Nelson's syndrome. Neurosurg Rev 8: 185-194, 1985

22. Ganz JC, Backlund EO, Thorsen FA: The effects of Gamma Knife surgery of pituitary adenomas on tumor growth and endocrinopathies. Stereotact Funct Neurosurg 61 (1 Suppl):30-37, 1993

23. Gicquel C, Le Bouc Y, Luton JP, Girard F, Bertagna X: Monoclonality of corticotroph macroadenomas in Cushing's disease. J Clin Endocrinol Metab 75:472-475, 1992

24. Gil-Cárdenas A, Herrera MF, Díaz-Polanco A, Rios JM, Pantoja JP: Nelson's syndrome after bilateral adrenalectomy for Cushing's disease. Surgery 141:147-152, 2007

25. Girkin CA, Comey CH, Lunsford LD, Goodman ML, Kline LB: Radiation optic neuropathy after stereotactic radiosurgery. Ophthalmology 104:1634-1643, 1997

26. Grabner P, Hauer-Jensen M, Jervell J, Flatmark A: Long-term results of treatment of Cushing's disease by adrenalectomy. Eur J Surg 157:461-464, 1991

27. Grua JR, Nelson DH: ACTH-producing pituitary tumors. Endocrinol Metab Clin North Am 20:319-362, 1991

28. Guilhaume B, Bertagna X, Thomsen M, Bricaire C, Vila-Porcile 
E, Olivier L, et al: Transsphenoidal pituitary surgery for the treatment of Cushing's disease: results in 64 patients and long term follow-up studies. J Clin Endocrinol Metab 66:1056-1064, 1988

29. Hawn MT, Cook D, Deveney C, Sheppard BC: Quality of life after laparoscopic bilateral adrenalectomy for Cushing's disease. Surgery 132:1064-1069, 2002

30. Heaney AP, Fernando M, Melmed S: PPAR-gamma receptor ligands: novel therapy for pituitary adenomas. J Clin Invest 111: 1381-1388, 2003

31. Heaney AP, Fernando M, Yong WH, Melmed S: Functional PPAR-gamma receptor is a novel therapeutic target for ACTHsecreting pituitary adenomas. Nat Med 8:1281-1287, 2002

32. Herman V, Fagin J, Gonsky R, Kovacs K, Melmed S: Clonal origin of pituitary adenomas. J Clin Endocrinol Metab 71: 1427-1433, 1990

33. Hopwood NJ, Kenny FM: Incidence of Nelson's syndrome after adrenalectomy for Cushing's disease in children: results of a nationwide survey. Am J Dis Child 131:1353-1356, 1977

34. Howlett TA, Plowman PN, Wass JA, Rees LH, Jones AE, Besser GM: Megavoltage pituitary irradiation in the management of Cushing's disease and Nelson's syndrome: long-term follow-up. Clin Endocrinol (Oxf) 31:309-323, 1989

35. Höybye C, Grenbäck E, Rähn T, Degerblad M, Thorén M, Hulting AL: Adrenocorticotropic hormone-producing pituitary tumors: 12 - to 22-year follow-up after treatment with stereotactic radiosurgery. Neurosurgery 49:284-292, 2001

36. Imai T, Funahashi H, Tanaka Y, Tobinaga J, Wada M, MoritaMatsuyama T, et al: Adrenalectomy for treatment of Cushing syndrome: results in 122 patients and long-term follow-up studies. World J Surg 20:781-787, 1996

37. Jenkins PJ, Trainer PJ, Plowman PN, Shand WS, Grossman AB, Wass JA, et al: The long-term outcome after adrenalectomy and prophylactic pituitary radiotherapy in adrenocorticotropin-dependent Cushing's syndrome. J Clin Endocrinol Metab 80: 165-171, 1995

38. Johnson RE, Scheithauer B: Massive hyperplasia of testicular adrenal rests in a patient with Nelson's syndrome. Am J Clin Pathol 77:501-507, 1982

39. Karl M, Von Wichert G, Kempter E, Katz DA, Reincke M, Monig $\mathrm{H}$, et al: Nelson's syndrome associated with a somatic frame shift mutation in the glucocorticoid receptor gene. J Clin Endocrinol Metab 81:124-129, 1996

40. Kasperlik-Zaluska A, Niegowska E, Migdalska B, Jeske W, Zielinski M: A correlative study between cortisol and ACTH in Cushing's disease following bilateral adrenalectomy and in Nelson's syndrome. Endokrynol Pol 43:314-321, 1992

41. Kasperlik-Zaluska AA, Bonicki W, Jeske W, Janik J, Zgliczynski W, Czernicki Z: Nelson's syndrome - 46 years later: clinical experience with 37 patients. Zentralbl Neurochir 67:14-20, 2006

42. Kasperlik-Zaluska AA, Jeske W: Management of Nelson's syndrome: observations in fifteen patients. Clin Endocrinol (Oxf) 55:819, 2001

43. Kasperlik-Zaluska AA, Nielubowicz J, Wislawski J, Hartwig W, Zaluska J, Jeske W, et al: Nelson's syndrome: incidence and prognosis. Clin Endocrinol (Oxf) 19:693-698, 1983

44. Kasperlik-Zaluska AA, Zgliczynski W, Jeske W, Zdunowski P: ACTH responses to somatostatin, valproic acid and dexamethasone in Nelson's syndrome. Neuro Endocrinol Lett 26:709-712, 2005

45. Kelestimur F, Utas C, Ozbakir O, Selcuklu A, Kandemir O, Ozcan $\mathrm{N}$ : The effects of octreotide in a patient with Nelson's syndrome. Postgrad Med J 72:53-54, 1996

46. Kelly PA, Samandouras G, Grossman AB, Afshar F, Besser GM, Jenkins PJ: Neurosurgical treatment of Nelson's syndrome. J Clin Endocrinol Metab 87:5465-5469, 2002

47. Kelly W, Adams JE, Laing I, Longson D, Davies D: Long-term treatment of Nelson's syndrome with sodium valproate. Clin Endocrinol (Oxf) 28:195-204, 1988

48. Kelly WF, MacFarlane IA, Longson D, Davies D, Sutcliffe H:
Cushing's disease treated by total adrenalectomy: long-term observations of 43 patients. Q J Med 52:224-231, 1983

49. Kemink L, Pieters G, Hermus A, Smals A, Kloppenborg P: Patient's age is a simple predictive factor for the development of Nelson's syndrome after total adrenalectomy for Cushing's disease. J Clin Endocrinol Metab 79:887-889, 1994

50. Kemink SA, Grotenhuis JA, De Vries J, Pieters GF, Hermus AR, Smals AG: Management of Nelson's syndrome: observations in fifteen patients. Clin Endocrinol (Oxf) 54:45-52, 2001

51. Kobayashi T, Kida Y, Mori Y: Gamma knife radiosurgery in the treatment of Cushing disease: long-term results. J Neurosurg 97 (5 Suppl):422-428, 2002

52. Kontogeorgos G, Kapranos N, Thodou E, Sambaziotis D, Tsagarakis S: Immunocytochemical accumulation of p53 in corticotroph adenomas: relationship with heat shock proteins and apoptosis. Pituitary 1:207-212, 1999

53. Lamberts SW, Klijn JG, de Quijada M, Timmermans HA, Uitterlinden P, de Jong FH, et al: The mechanism of the suppressive action of bromocriptine on adrenocorticotropin secretion in patients with Cushing's disease and Nelson's syndrome. J Clin Endocrinol Metab 51:307-311, 1980

54. Lamberts SW, Verleun T, Bons EG, Uitterlinden P, Oosterom R: Effect of cyproheptadine, desmethylcyproheptadine, gammaamino-butyric acid and sodium valproate on adrenocorticotrophin secretion by cultured pituitary tumor cells from three patients with Nelson's syndrome. J Endocrinol 96:401-406, 1983

55. Landman RE, Horwith M, Peterson RE, Khandji AG, Wardlaw SL: Long-term survival with ACTH-secreting carcinoma of the pituitary: a case report and review of the literature. J Clin Endocrinol Metab 87:3084-3089, 2002

56. Loli P, Berselli ME, Frascatani F, Muratori F, Tagliaferri M: Lack of ACTH lowering effect of sodium valproate in patients with ACTH hypersecretion. J Endocrinol Invest 7:93-96, 1984

57. Loli P, Berselli ME, Vignati F, De Grandi C, Tagliaferri M: Size reduction of an ACTH-secreting pituitary macroadenoma in Nelson's syndrome by sodium valproate: effect of withdrawal and reinstitution of treatment. Acta Endocrinol (Copenh) 119: 435-442, 1988

58. Lormeau B, Miossec P, Sibony M, Valensi P, Attali JR: Adrenocorticotropin-producing pituitary carcinoma with liver metastasis. J Endocrinol Invest 20:230-236, 1997

59. Machado AL, Nomikos P, Kiesewetter F, Fahlbusch R, Buchfelder M: DNA-flow cytometry of 207 pituitary adenomas: ploidy, proliferation, and prognosis. J Endocrinol Invest 28: 795-801, 2005

60. Mahmoud-Ahmed AS, Suh JH: Radiation therapy for Cushing's disease: a review. Pituitary 5:175-180, 2002

61. Mampalam TJ, Tyrrell JB, Wilson CB: Transsphenoidal microsurgery for Cushing disease. A report of 216 cases. Ann Intern Med 109:487-493, 1988

62. Manolas KJ, Farmer HM, Wilson HK, Kennedy AL, Joplin GF, Montgomery DA, et al: The pituitary before and after adrenalectomy for Cushing's syndrome. World J Surg 8:374-387, 1984

63. Mauermann WJ, Sheehan JP, Chernavvsky DR, Laws ER, Steiner L, Vance ML: Gamma Knife surgery for adrenocorticotropic hormone-producing pituitary adenomas after bilateral adrenalectomy. J Neurosurg 106:988-993, 2007

64. McCance DR, Gordon DS, Fannin TF, Hadden DR, Kennedy L, Sheridan B, et al: Assessment of endocrine function after transsphenoidal surgery for Cushing's disease. Clin Endocrinol (Oxf) 38:79-86, 1993

65. McCance DR, Russell CF, Kennedy TL, Hadden DR, Kennedy L, Atkinson AB: Bilateral adrenalectomy: low mortality and morbidity in Cushing's disease. Clin Endocrinol (Oxf) 39:315-321, 1993

66. McCutcheon I, Oldfield E: Cortisol: regulation, disorders, and clinical evaluation, in Barrow D, Selman W (eds): Neuroendocrinology: Concepts in Neurosurgery, vol 5 . Baltimore: Williams \& Wilkins, 1992, pp 117-173. 
67. McCutcheon IE: Stereotactic radiosurgery for patients with ACTH-producing pituitary adenomas after prior adrenalectomy. Int J Radiat Oncol Biol Phys 54:640-641, 2002

68. McNicol AM, Carbajo-Perez E: Aspects of anterior pituitary growth, with special reference to corticotrophs. Pituitary 1:257-268, 1999

69. Meij BP, Lopes MB, Vance ML, Thorner MO, Laws ER Jr: Double pituitary lesions in three patients with Cushing's disease. Pituitary 3:159-168, 2000

70. Mercado-Asis LB, Yanovski JA, Tracer HL, Chik CL, Cutler GB Jr: Acute effects of bromocriptine, cyproheptadine, and valproic acid on plasma adrenocorticotropin secretion in Nelson's syndrome. J Clin Endocrinol Metab 82:514-517, 1997

71. Mindermann T, Wilson CB: Age-related and gender-related occurrence of pituitary adenomas. Clin Endocrinol (Oxf) 41: 359-364, 1994

72. Moore TJ, Dluhy RG, Williams GH, Cain JP: Nelson's syndrome: frequency, prognosis, and effect of prior pituitary irradiation. Ann Intern Med 85:731-734, 1976

73. Moreira AC, Castro M, Machado HR: Longitudinal evaluation of adrenocorticotrophin and beta-lipotrophin plasma levels following bilateral adrenalectomy in patients with Cushing's disease. Clin Endocrinol (Oxf) 39:91-96, 1993

74. Mounier C, Pasquet F, Trouillas J, Perrin G, Jouanneau E, BorsonChazot F, et al: [Nelson's syndrome: course of aggressive pituitary corticotroph adenoma.] Ann Endocrinol (Paris) 68:28-33, 2007 (Fr)

75. Mullan KR, Leslie H, McCance DR, Sheridan B, Atkinson AB: The PPAR-gamma activator rosiglitazone fails to lower plasma ACTH levels in patients with Nelson's syndrome. Clin Endocrinol (Oxf) 64:519-522, 2006

76. Munir A, Song F, Ince P, Walters SJ, Ross R, Newell-Price J: Ineffectiveness of rosiglitazone therapy in Nelson's syndrome. J Clin Endocrinol Metab 92:1758-1763, 2007

77. Nagesser SK, van Seters AP, Kievit J, Hermans J, Krans HM, van de Velde CJ: Long-term results of total adrenalectomy for Cushing's disease. World J Surg 24:108-113, 2000

78. Nelson DH, Meakin JW, Dealy JB Jr, Matson DD, Emerson K Jr, Thorn GW: ACTH-producing tumor of the pituitary gland. $\mathbf{N}$ Engl J Med 259:161-164, 1958

79. Nelson DH, Meakin JW, Thorn GW: ACTH-producing pituitary tumors following adrenalectomy for Cushing's syndrome. Ann Intern Med 52:560-569, 1960

80. Nelson DH, Sprunt JG, Mims RB: Plasma ACTH determinations in 58 patients before or after adrenalectomy for Cushing's syndrome. J Clin Endocrinol Metab 26:722-728, 1966

81. Newell-Price J, Bertagna X, Grossman AB, Nieman LK: Cushing's syndrome. Lancet 367:1605-1617, 2006

82. Ntalles K, Kostoglou-Athanassiou I, Georgiou E, Ikkos D: Paratesticular tumors in a patient with Nelson's syndrome. Horm Res 45:291-294, 1996

83. Oldfield EH, Schulte HM, Chrousos GP, Gold PW, Benker G, Peterson RE, et al: Corticotropin-releasing hormone (CRH) stimulation in Nelson's syndrome: response of adrenocorticotropin secretion to pulse injection and continuous infusion of CRH. J Clin Endocrinol Metab 62:1020-1026, 1986

84. Orth DN: Corticotropin-releasing hormone in humans. Endocr Rev 13:164-191, 1992

85. Pereira MA, Halpern A, Salgado LR, Mendonça BB, Nery M, Liberman B, et al: A study of patients with Nelson's syndrome. Clin Endocrinol (Oxf) 49:533-539, 1998

86. Pernicone PJ, Scheithauer BW, Sebo TJ, Kovacs KT, Horvath E, Young WF Jr, et al: Pituitary carcinoma: a clinicopathologic study of 15 cases. Cancer 79:804-812, 1997

87. Petrini L, Gasperi M, Pilosu R, Marcello A, Martino E: Long-term treatment of Nelson's syndrome by octreotide: a case report. J Endocrinol Invest 17:135-139, 1994

88. Pivonello R, Ferone D, de Herder WW, Kros JM, De Caro ML,
Arvigo M, et al: Dopamine receptor expression and function in corticotroph pituitary tumors. J Clin Endocrinol Metab 89: 2452-2462, 2004

89. Pluta RM, Nieman L, Doppman JL, Watson JC, Tresser N, Katz DA, et al: Extrapituitary parasellar microadenoma in Cushing's disease. J Clin Endocrinol Metab 84:2912-2923, 1999

90. Pollock BE, Young WF Jr: Stereotactic radiosurgery for patients with ACTH-producing pituitary adenomas after prior adrenalectomy. Int J Radiat Oncol Biol Phys 54:839-841, 2002

91. Prescott RW, Ratcliffe WA, Taylor PK: Effect of an oral serotonin antagonist, ketanserin, on plasma ACTH concentrations in Nelson's syndrome. Br Med J (Clin Res Ed) 289:787-788, 1984

92. Ram Z, Nieman LK, Cutler GB Jr, Chrousos GP, Doppman JL, Oldfield EH: Early repeat surgery for persistent Cushing's disease. J Neurosurg 80:37-45, 1994

93. Rees DA, Hanna FW, Davies JS, Mills RG, Vafidis J, Scanlon MF: Long-term follow-up results of transsphenoidal surgery for Cushing's disease in a single centre using strict criteria for remission. Clin Endocrinol (Oxf) 56:541-551, 2002

94. Rees JR, Zilva JF: Diabetes insipidus complicating total adrenalectomy. J Clin Pathol 12:530-534, 1959

95. Reincke M, Allolio B, Kaulen D, Jaursch-Hancke C, Winkelmann W: The effect of sodium valproate in Cushing's disease, Nelson's syndrome and Addison's disease. Klin Wochenschr 66:686-689, 1988

96. Reitmeyer M, Vance ML, Laws ER Jr: The neurosurgical management of Cushing's disease. Mol Cell Endocrinol 197:73-79, 2002

97. Rennert J, Doerfler A: Imaging of sellar and parasellar lesions. Clin Neurol Neurosurg 109:111-124, 2007

98. Saffran M, Schally AV: The release of corticotrophin by anterior pituitary tissue in vitro. Can J Biochem Physiol 33:408-415, 1955

99. Sheehan JM, Vance ML, Sheehan JP, Ellegala DB, Laws ER Jr: Radiosurgery for Cushing's disease after failed transsphenoidal surgery. J Neurosurg 93:738-742, 2000

100. Shekarriz M, Schneider C, Sabanegh E, Kempter F, Waldherr R: Excessive testosterone production in a patient with Nelson syndrome and bilateral testicular tumors. Urol Int 56:200-203, 1996

101. Shibasaki T, Nakahara M, Shizume K, Kiyosawa Y, Suda T, Demura H, et al: Pituitary adenomas that caused Cushing's disease or Nelson's syndrome are not responsive to ovine corticotropin-releasing factor in vitro. J Clin Endocrinol Metab 56:414-416, 1983

102. Shraga-Slutzky I, Shimon I, Weinshtein R: Clinical and biochemical stabilization of Nelson's syndrome with long-term low-dose cabergoline treatment. Pituitary 9:151-154, 2006

103. Sonino N, Boscaro M: Medical therapy for Cushing's disease. Endocrinol Metab Clin North Am 28:211-222, 1999

104. Sonino N, Fava GA, Fallo F, Franceschetto A, Belluardo P, Boscaro M: Effect of the serotonin antagonists ritanserin and ketanserin in Cushing's disease. Pituitary 3:55-59, 2000

105. Sonino N, Zielezny M, Fava GA, Fallo F, Boscaro M: Risk factors and long-term outcome in pituitary-dependent Cushing's disease. J Clin Endocrinol Metab 81:2647-2652, 1996

106. Sprague RG: Cushing's syndrome with special reference to bilateral adrenalectomy. Proc R Soc Med 46:1070-1077, 1953

107. Suda T, Liotta AS, Krieger DT: beta-Endorphin is not detectable in plasma from normal human subjects. Science 202:221-223, 1978

108. Swearingen B, Barker FG II, Zervas NT: The management of pituitary adenomas: the MGH experience. Clin Neurosurg 45:48-56, 1999

109. Thomas CG Jr, Smith AT, Benson M, Griffith J: Nelson's syndrome after Cushing's disease in childhood: a continuing problem. Surgery 96:1067-1077, 1984

110. Thorén M, Höybye C, Grenbäck E, Degerblad M, Rähn T, 
Hulting AL: The role of gamma knife radiosurgery in the management of pituitary adenomas. J Neurooncol 54:197-203, 2001

111. Tsigos C, Papanicolaou DA, Chrousos GP: Advances in the diagnosis and treatment of Cushing's syndrome. Baillieres Clin Endocrinol Metab 9:315-336, 1995

112. Tyrrell JB, Lorenzi M, Gerich JE, Forsham PH: Inhibition by somatostatin of ACTH secretion in Nelson's syndrome. J Clin Endocrinol Metab 40:1125-1127, 1975

113. Vale W, Spiess J, Rivier C, Rivier J: Characterization of a 41residue ovine hypothalamic peptide that stimulates secretion of corticotropin and beta-endorphin. Science 213:1394-1397, 1981

114. van Aken MO, Pereira AM, van den Berg G, Romijn JA, Veldhuis JD, Roelfsema F: Profound amplification of secretory-burst mass and anomalous regularity of ACTH secretory process in patients with Nelson's syndrome compared with Cushing's disease. Clin Endocrinol (Oxf) 60:765-772, 2004

115. Vance ML: Treatment of patients with a pituitary adenoma: one clinician's experience. Neurosurg Focus 16:E1, 2004

116. Vella A, Thompson GB, Grant CS, van Heerden JA, Farley DR, Young WF Jr: Laparoscopic adrenalectomy for adrenocorticotropin-dependent Cushing's syndrome. J Clin Endocrinol Metab 86:1596-1599, 2001

117. Warnet A: The role of octreotide (Sandostatin) in non-growth hormone-, non-thyroid-stimulating hormone-, and non-prolactin-secreting adenomas. Metabolism 41 (2 Suppl):59-61, 1992

118. Whitehead HM, Beacom R, Sheridan B, Atkinson AB: The ef- fect of cyproheptadine and/or bromocriptine on plasma ACTH levels in patients cured of Cushing's disease by bilateral adrenalectomy. Clin Endocrinol (Oxf) 32:193-201, 1990

119. Wolffenbuttel BH, Kitz K, Beuls EM: Beneficial gamma-knife radiosurgery in a patient with Nelson's syndrome. Clin Neurol Neurosurg 100:60-63, 1998

120. Wolfsen AR, Odell WD: The dose-response relationship of ACTH and cortisol in Cushing's disease. Clin Endocrinol (Oxf) 12:557-568, 1980

121. Xing B, Ren Z, Su C, Wang R, Yang Y, Hu Y: Microsurgical treatment of Nelson's syndrome. Chin Med J (Engl) 115: 1150-1152, 2002

122. Yoshida K, Sato A, Yamaguchi Y, Ichikawa Y: ACTH secretion during sleep in a patient with Nelson's syndrome. Endocrinol Jpn 22:347-349, 1975

123. Zielinski G, Podgórski JK, Koziarski A, Potakiewicz Z, Warczynska A, Zgliczynski W, et al: [Transsphenoidal surgery of secretory and invasive pituitary adenomas (somatotropinoma or corticotropinoma)—own experiences.] Przegl Lek 61:928-934, 2004 (Pol)

Manuscript submitted June 15, 2007.

Accepted July 26, 2007.

Address correspondence to: Ali R. Malek, M.D., Department of Neurosurgery, University of South Florida, 4 Columbia Drive, Suite 730, Tampa, Florida 33606. email: amalek@ health.usf.edu. 